\title{
EFFECTS OF ACUTE REDUCTION OF CARDIAC OUTPUT ON THE RENAL CIRCULATION OF THE DOG ${ }^{1}$
}

\author{
BY ROBERT M. BERNE 2 AND MATTHEW N. LEVY 3 \\ (From the Department of Physiology, Western Reserve University Medical School, Cleveland)
}

(Submitted for publication October 1, 1949; accepted, December 5, 1949)

Clinical studies on congestive heart failure have revealed a disproportionately large decrease in renal blood flow as compared to the reduction in cardiac output. Merrill (1) has reported an average diminution of renal blood flow to about onefifth of normal in a large series of decompensated patients whose average cardiac output had decreased to approximately one-half of normal. An average reduction of renal blood flow to about onethird of normal has been described by Mokotoff, Ross, and Leiter (2) in a similar group of patients, but cardiac outputs were not determined. Since these changes occurred in patients who presumably had arterial pressures within or near normal ranges, the question arises whether a reduction of cardiac output per se produces such a marked impairment of the renal circulation. These findings have prompted us to investigate the effects of acutely reduced cardiac output upon the renal blood flow under experimental conditions in which the cardiac output could be rapidly altered.

In a previous paper (3), we described the cardiovascular dynamics of acute graded stenosis of the pulmonary artery, and demonstrated that it is possible to achieve significant reduction of cardiac output while maintaining the arterial pressure within normal limits. This was accomplished by compressing the pulmonary artery to a degree where right atrial pressures were significantly elevated while arterial pressures were only slightly reduced or remained essentially unchanged. We suggested that this procedure would be a convenient and relatively simple method for simulating acutely the conditions which are induced chronically in clinical congestive heart failure. This being the case, the procedure would afford an opportunity for assaying the responses of the

\footnotetext{
1 This investigation was supported by a research grant from the National Heart Institute, U. S. Public Health Service.

${ }^{2}$ Sarah Welt Fellow.

${ }^{3}$ U. S. Public Health Service Postdoctorate Research Fellow.
}

renal circulation to degrees of reduced cardiac output which would not affect the renal blood flow indirectly through concurrent changes in arterial $(4,5)$ or venous $(6,7)$ pressures. In the present series of experiments, therefore, we have applied clearance techniques in anesthetized dogs subjected to graded pulmonary artery stenosis to study the effects of acutely reduced cardiac output upon the renal circulation.

\section{METHODS}

A series of nine satisfactory experiments was performed on dogs varying in weight from 17.0 to $26.5 \mathrm{~kg}$. All dogs were anesthetized with an initial intravenous dose of sodium pentobarbital (30 mg./kg.), and were given additional small doses as necessary to maintain a fairly light anesthesia. No pentobarbital was given during experimental periods, and a time interval of at least 30 minutes was allowed to elapse after administration before subsequent observations were made.

The thorax was opened by resection of the fourth left rib, and respiration was maintained artificially through a large tracheal cannula. The pulmonary artery was separated from the base of the aorta by careful dissection, and a brass clamp was placed about the pulmonary artery near its origin. Gradual compression was exerted by means of a screw-type arrangement which could be locked in place at any desired position.

In the first five experiments, the aortic pressure was registered optically by means of a modified Gregg manometer from the arch of the aorta through a cannula inserted down the left carotid artery. The right atrial pressure was similarly recorded through a cannula passed by way of the right external jugular vein. The mean arterial pressure was determined by planimetry, and the right atrial pressure pulse was measured at the " $\mathrm{V}$ " point; that is, the point just before the opening of the tricuspid valves. The "V" point was chosen as the point of reference, since the closed tricuspid valves separate the right ventricle from the central venous system, and the measured pressure depends solely upon the quantity of blood contained in the central venous reservoir and the volumeelasticity characteristics of the right atrium and great veins (8). It became evident, however, that precise determination of the central venous pressure was not essential to implement our studies, and so in the last four experiments of our series, the mean right atrial pressure was read periodically from a water manometer, and the 
mean arterial pressure was recorded on a smoked drum by means of a damped mercury manometer.

For the estimation of cardiac output by the Fick principle, oxygen consumption was measured by placing a modified Benedict-Roth spirometer in series with an intermittent positive pressure respirator. The spirometer employed was the model devised by Harris and Matlock (9) for use in open-chested animals, improved by introducing suction between the two tanks of the apparatus in order to overcome the resistance to expiration. Oxygen consumption determinations done pre-operatively agreed closely in all cases with values obtained in the same animal with the chest open. A post-mortem oxygen consumption was determined in each case as a check against oxygen loss through leaks or by diffusion out of the lungs in the open-chested dog, and the post-mortem oxygen loss was then subtracted from all the experimental values. In all but one experiment, the post-mortem value was less than 10 per cent of the smallest experimental result.

Arterial and mixed venous blood samples were collected simultaneously over mercury in greased syringes from a femoral artery and a small branch of the pulmonary artery, respectively. In the pre-operative determinations of cardiac output, however, samples of mixed venous blood were obtained from the right ventricle. The samples were kept on ice in the original syringes sealed with mercury, and oxygen content was determined in duplicate by the method of Roughton and Scholander (10) within 12 hours of the time of collection.

Renal clearance studies were performed using creatinine as a measure of glomerular filtration rate and paraaminohippurate (PAH) as a measure of effective renal plasma flow. Mannitol was used as an osmotic diuretic to assure a urine flow greater than $2.0 \mathrm{cc} . / \mathrm{min}$. during control periods, and greater than $1.5 \mathrm{cc} . / \mathrm{min}$. during constriction periods. Following a priming dose, suitable blood levels of creatinine and PAH were maintained by continuous slow intravenous infusion at a constant rate by means of a mercury pump. The alkaline picrate method of Folin and Wu (11) was used for creatinine analysis of urine and sodium tungstate plasma filtrates. PAH was determined by the method of Smith and his associates (12) on cadmium sulfate plasma flitrates and urine. All analyses were done in duplicate. Urine was collected by catheterization of the bladder in the first two experiments and in all "pre-operative" control studies, and by catheterization of the ureters in all other clearance periods. Blood samples were drawn from the femoral artery at the beginning and end of each pair of periods, and blood levels were interpolated to the mid-points of each period by plotting on semi-log paper.

In six of the experiments at least two different degrees of pulmonary artery constriction were produced, and were maintained for approximately $\mathbf{3 0}$ or $\mathbf{4 0}$ minutes, followed in each case by complete release of the constriction. The degree of compression and consequent reduction in cardiac output was gauged by the rise in central venous pressure and fall in arterial pressure, as discussed in our previous paper (3). In two other experiments, after control periods, the pulmonary artery was compressed for a longer period of time. In one of these (Exp. BL 19, Table I), the constriction was maintained for four hours, followed by a recovery period, while in the other (Exp. BL 25, Table I), the duration of constriction was prematurely terminated after two hours by the accidental death of the animal. In the ninth experiment of this series (Table II), extraction ratios for $\mathrm{PAH}$ were determined during control and constriction periods.

In each experiment, no compression was applied to the pulmonary artery until at least one pair of control periods had been obtained. Post-operative control observations were made in each experiment after all surgical procedures had been completed, and in three experiments (BL 24, 25, and 26), a preliminary pair of pre-operative control periods also was run following cannulation of the trachea, left carotid artery and right jugular vein.

Blood withdrawn for analyses was replaced by heparinized blood from donor dogs at the completion of each pair of observation periods. In addition, 150 to $400 \mathrm{cc}$. of 0.9 per cent saline were administered intravenously between each pair of periods to compensate for the dehydrating effect of the mannitol diuretic. Hematocrit determinations served as guides for the quantity of saline to be given. At least 30 minutes were allowed to elapse following the administration of blood and saline before any subsequent experimental tests were performed.

\section{RESULTS}

Arterial and central venous pressures. Pressure changes in the aorta and right atrium were employed as convenient and immediately available criteria for estimating approximately the degree of reduction of cardiac output during the actual course of the experiment as stated above. After a pair of control periods the pulmonary artery was constricted until a definite elevation of mean central venous pressure (ca. $5 \mathrm{~cm}$. water) was elicited, unaccompanied by any drop in mean arterial pressure which would in itself affect renal blood flow significantly $(4,5)$. Experimental observations made under these conditions are arbitrarily included under the designation "moderate constriction periods" (Table I). Following a subsequent interval of release of compression in four experiments (Table I, BL 10,15, 16, and 24), the pulmonary artery was constricted to a still greater degree. Such "severe constriction periods" were designed so that the pulmonary artery was occluded to the maximal degree which would still maintain the mean arterial pressure above $80 \mathrm{~mm}$. $\mathrm{Hg}$.

During the release periods which followed each pair of constriction periods, the aortic and right atrial pressures approached control levels, but usu- 
ally did not return completely to the original values. No consistent changes in heart rate were observed.

In experiments BL 11,15 , and 16 (Table I), the pulmonary artery was constricted between control and moderate constriction periods to the point at which no alteration occurred in aortic or right atrial pressures, but where a prominent systolic thrill was palpable, to determine whether cardiac output was reduced before any pressure relationships were disturbed. No significant changes in cardiac outputs or renal blood flows were observed, so these periods were omitted from our tables and graphs.

Cardiac output. In each experiment there was a tendency for the cardiac output to decline during the course of the experiment (Table I). This is probably partly the result of anesthesia, since a similar phenomenon has been reported in dogs anesthetized with sodium barbital (13). However, cardiac output determinations made soon

TABLE I

Data from eight experiments

\begin{tabular}{|c|c|c|c|c|c|c|c|c|c|c|c|}
\hline $\begin{array}{c}\text { Expt. no. } \\
\text { (Wt. of dog) } \\
\text { (Wt. of kidneys) }\end{array}$ & Procedures & Time & M.A.P. & $\begin{array}{l}\text { Rt. atr. } \\
\text { pressure }\end{array}$ & $\begin{array}{l}\text { Cardiac } \\
\text { output }\end{array}$ & $\begin{array}{l}\text { Renal } \\
\text { W.B.F. }\end{array}$ & $\begin{array}{c}\text { Renal } \\
\text { fraction }\end{array}$ & $\begin{array}{l}\text { Filt. } \\
\text { rate }\end{array}$ & $\begin{array}{l}\text { Filt. } \\
\text { fract. }\end{array}$ & $\begin{array}{l}\text { T.P.R. } \\
\text { in A.U. } \\
\times 10^{3}\end{array}$ & $\begin{array}{l}\text { Renal } \\
\text { resistance } \\
\text { A.U. } \times 10^{3}\end{array}$ \\
\hline $\begin{array}{l}\text { BL } 10 \\
(26.5 \mathrm{~kg} .) \\
(174 \mathrm{gm} .)\end{array}$ & $\begin{array}{l}\text { Post-op. } \\
\text { Control } \\
\text { Mod. Const. } \\
\text { Severe Const. } \\
\text { Release } \\
\text { Severe Const. }\end{array}$ & $\begin{array}{r}\min . \\
0 \\
147 \\
299 \\
361 \\
464\end{array}$ & $\begin{array}{c}m \boldsymbol{m} . \boldsymbol{H} \boldsymbol{g} \\
137 \\
122 \\
99 \\
112 \\
104\end{array}$ & $\begin{array}{c}m m . \mathrm{H}_{2} \mathrm{O} \\
37 \\
37 \\
108 \\
195 \\
46 \\
169\end{array}$ & $\begin{array}{c}l . / \min . \\
\\
3.53 \\
1.76 \\
1.11 \\
2.40 \\
1.35\end{array}$ & $\begin{array}{c}c c . / \min . \\
507 \\
418 \\
351 \\
253 \\
255\end{array}$ & $\begin{array}{c}\text { per cent } \\
\\
14.5 \\
23.7 \\
31.6 \\
10.6 \\
18.9\end{array}$ & $\begin{array}{c}c c . / \min . \\
94.7 \\
106.1 \\
80.7 \\
71.7 \\
66.8\end{array}$ & $\begin{array}{l}.370 \\
.517 \\
.505 \\
.513 \\
.587\end{array}$ & $\begin{array}{l}3.10 \\
5.54 \\
7.13 \\
3.73 \\
6.16\end{array}$ & $\begin{array}{l}21.6 \\
23.3 \\
22.5 \\
35.4 \\
32.6\end{array}$ \\
\hline $\begin{array}{l}\text { BL } 11 \\
\text { (17.0 kg.) } \\
\text { (126 gm.) }\end{array}$ & $\begin{array}{l}\text { Post-op. } \\
\text { Control } \\
\text { Mod. Const. } \\
\text { Mod. Const. } \\
\text { Release } \\
\text { Release }\end{array}$ & $\begin{array}{r}0 \\
11 \\
233 \\
245 \\
304 \\
316\end{array}$ & $\begin{array}{r}94 \\
101 \\
100 \\
97 \\
98 \\
107\end{array}$ & $\begin{array}{l}30 \\
23 \\
53 \\
92 \\
65 \\
55\end{array}$ & $\begin{array}{l}3.05 \\
3.63 \\
0.95 \\
1.13 \\
1.91 \\
1.61\end{array}$ & $\begin{array}{l}372 \\
373 \\
265 \\
205 \\
239 \\
257\end{array}$ & $\begin{array}{l}12.2 \\
10.3 \\
27.9 \\
18.2 \\
12.5 \\
16.0\end{array}$ & $\begin{array}{l}64.9 \\
66.7 \\
82.9 \\
63.1 \\
81.4 \\
79.9\end{array}$ & $\begin{array}{l}.290 \\
.281 \\
.496 \\
.487 \\
.503 \\
.518\end{array}$ & $\begin{array}{l}2.46 \\
2.22 \\
8.41 \\
6.86 \\
4.10 \\
5.31\end{array}$ & $\begin{array}{l}20.2 \\
21.6 \\
30.2 \\
37.8 \\
32.8 \\
33.3\end{array}$ \\
\hline $\begin{array}{l}\text { BL } 15 \\
(20.5 \mathrm{~kg} .) \\
(126 \mathrm{gm} .)\end{array}$ & $\begin{array}{l}\text { Post-op. } \\
\text { Control } \\
\text { Mod. Const. } \\
\text { Mod. Const. } \\
\text { Release } \\
\text { Release } \\
\text { Severe Const. } \\
\text { Severe Const. } \\
\text { Release } \\
\text { Release }\end{array}$ & $\begin{array}{r}0 \\
10 \\
204 \\
214 \\
245 \\
255 \\
308 \\
318 \\
348 \\
358\end{array}$ & $\begin{array}{r}115 \\
115 \\
91 \\
93 \\
115 \\
108 \\
82 \\
80 \\
115 \\
117\end{array}$ & $\begin{array}{r}68 \\
43 \\
110 \\
112 \\
67 \\
55 \\
130 \\
130 \\
50 \\
43\end{array}$ & $\begin{array}{l}1.78 \\
1.53 \\
0.92 \\
1.00 \\
1.27 \\
1.27 \\
0.88 \\
0.91 \\
1.66 \\
1.52\end{array}$ & $\begin{array}{l}171 \\
164 \\
207 \\
173 \\
214 \\
188 \\
151 \\
161 \\
148 \\
164\end{array}$ & $\begin{array}{r}9.6 \\
10.7 \\
22.4 \\
17.3 \\
16.8 \\
14.8 \\
17.2 \\
17.7 \\
8.9 \\
10.8\end{array}$ & $\begin{array}{l}39.8 \\
37.7 \\
56.3 \\
45.7 \\
54.1 \\
56.3 \\
51.0 \\
49.4 \\
50.1 \\
54.7\end{array}$ & $\begin{array}{l}.398 \\
.400 \\
.446 \\
.443 \\
.400 \\
.498 \\
.562 \\
.517 \\
.510 \\
.536\end{array}$ & $\begin{array}{l}5.16 \\
6.01 \\
7.90 \\
7.43 \\
7.24 \\
6.79 \\
7.45 \\
7.02 \\
5.54 \\
6.15\end{array}$ & $\begin{array}{l}53.7 \\
56.0 \\
35.1 \\
42.9 \\
43.1 \\
45.9 \\
43.4 \\
39.7 \\
62.1 \\
57.0\end{array}$ \\
\hline $\begin{array}{l}\text { BL } 16 \\
(19.5 \mathrm{~kg} .) \\
(107 \mathrm{gm} .)\end{array}$ & $\begin{array}{l}\text { Post-op. } \\
\text { Control } \\
\text { Mod. Const. } \\
\text { Mod. Const. } \\
\text { Release } \\
\text { Release } \\
\text { Severe Const. } \\
\text { Severe Const. } \\
\text { Release } \\
\text { Release }\end{array}$ & $\begin{array}{r}0 \\
10 \\
158 \\
168 \\
197 \\
207 \\
260 \\
270 \\
297 \\
307\end{array}$ & $\begin{array}{r}135 \\
130 \\
115 \\
110 \\
118 \\
114 \\
97 \\
104 \\
120 \\
121\end{array}$ & $\begin{array}{r}86 \\
84 \\
101 \\
100 \\
62 \\
60 \\
103 \\
90 \\
81 \\
65\end{array}$ & $\begin{array}{l}3.50 \\
3.53 \\
1.71 \\
1.95 \\
1.96 \\
1.93 \\
1.25 \\
1.38 \\
2.22 \\
2.01\end{array}$ & $\begin{array}{l}368 \\
393 \\
258 \\
254 \\
297 \\
289 \\
218 \\
184 \\
228 \\
223\end{array}$ & $\begin{array}{l}10.3 \\
11.1 \\
15.1 \\
13.0 \\
15.2 \\
15.0 \\
17.5 \\
13.3 \\
10.3 \\
11.1\end{array}$ & $\begin{array}{l}62.4 \\
68.9 \\
72.2 \\
69.6 \\
70.9 \\
75.8 \\
59.1 \\
54.7 \\
63.7 \\
65.6\end{array}$ & $\begin{array}{l}.264 \\
.266 \\
.446 \\
.434 \\
.381 \\
.432 \\
.443 \\
.470 \\
.447 \\
.477\end{array}$ & $\begin{array}{l}3.08 \\
2.94 \\
5.37 \\
4.51 \\
4.81 \\
4.72 \\
6.20 \\
6.02 \\
4.32 \\
4.81\end{array}$ & $\begin{array}{l}29.3 \\
26.4 \\
35.6 \\
34.6 \\
31.7 \\
31.5 \\
35.6 \\
45.2 \\
42.1 \\
43.4\end{array}$ \\
\hline $\begin{array}{l}\text { BL } 19 \\
(24.0 \mathrm{~kg} .) \\
(132 \mathrm{gm} .)\end{array}$ & $\begin{array}{l}\text { Post-op. } \\
\text { Control } \\
\text { Mod. Const. } \\
\text { Mod. Const. } \\
\text { Slight } \\
\text { additional } \\
\text { constr. }\end{array}$ & $\begin{array}{r}0 \\
10 \\
88 \\
98 \\
144 \\
154 \\
196 \\
208 \\
249 \\
259 \\
308 \\
318 \\
362 \\
372\end{array}$ & $\begin{array}{r}100 \\
100 \\
92 \\
93 \\
103 \\
100 \\
101 \\
100 \\
103 \\
99 \\
102 \\
107 \\
112 \\
120\end{array}$ & $\begin{array}{r}32 \\
32 \\
115 \\
105 \\
70 \\
74 \\
89 \\
89 \\
83 \\
83 \\
97 \\
102 \\
74 \\
61\end{array}$ & $\begin{array}{l}2.80 \\
2.95 \\
2.04 \\
2.26 \\
1.75 \\
2.51 \\
2.28 \\
2.10 \\
1.50 \\
1.54 \\
1.37 \\
1.53 \\
1.92 \\
1.77\end{array}$ & $\begin{array}{l}472 \\
421 \\
406 \\
394 \\
336 \\
361 \\
313 \\
335 \\
313 \\
288 \\
302 \\
328 \\
296 \\
309\end{array}$ & $\begin{array}{l}16.9 \\
14.3 \\
19.9 \\
17.4 \\
19.2 \\
14.3 \\
13.7 \\
16.0 \\
20.9 \\
18.7 \\
22.0 \\
21.4 \\
15.4 \\
17.5\end{array}$ & $\begin{array}{l}65.5 \\
71.4 \\
69.2 \\
67.3 \\
73.7 \\
82.2 \\
78.1 \\
79.9 \\
70.2 \\
68.0 \\
69.4 \\
70.9 \\
74.1 \\
68.6\end{array}$ & $\begin{array}{l}.350 \\
.378 \\
.412 \\
.403 \\
.428 \\
.478 \\
.470 \\
.496 \\
.468 \\
.489 \\
.510 \\
.518 \\
.518 \\
.483\end{array}$ & $\begin{array}{l}2.85 \\
2.71 \\
3.60 \\
3.29 \\
4.70 \\
3.18 \\
3.54 \\
3.80 \\
5.45 \\
5.14 \\
5.95 \\
5.59 \\
4.66 \\
5.42\end{array}$ & $\begin{array}{l}16.9 \\
19.0 \\
18.1 \\
18.9 \\
24.5 \\
22.1 \\
25.8 \\
23.9 \\
26.3 \\
27.5 \\
27.0 \\
26.1 \\
30.2 \\
31.0\end{array}$ \\
\hline
\end{tabular}


TABLE I (Continued)

\begin{tabular}{|c|c|c|c|c|c|c|c|c|c|c|c|}
\hline $\begin{array}{c}\text { Expt. no. } \\
\text { (Wt. of dog) } \\
\text { (Wt. of kidneys) }\end{array}$ & Procedures & Time & M.A.P. & $\begin{array}{l}\text { Rt. atr. } \\
\text { pressure }\end{array}$ & $\begin{array}{l}\text { Cardiac } \\
\text { output }\end{array}$ & $\begin{array}{l}\text { Renal } \\
\text { W.B.F. }\end{array}$ & $\begin{array}{c}\text { Renal } \\
\text { fraction }\end{array}$ & $\begin{array}{l}\text { Filt. } \\
\text { rate }\end{array}$ & $\begin{array}{l}\text { Filt. } \\
\text { fract. }\end{array}$ & $\begin{array}{l}\text { T.P.R. } \\
\text { in A.U. } \\
\times 10^{3}\end{array}$ & $\begin{array}{l}\text { Renal } \\
\text { resistance } \\
\text { A.U. } \times 10^{2}\end{array}$ \\
\hline $\begin{array}{l}\text { BL } 24 \\
(21.5 \mathrm{~kg} .) \\
(124 \mathrm{gm} .)\end{array}$ & $\begin{array}{l}\text { Pre-op. } \\
\text { Control } \\
\text { Post-op. } \\
\text { Control } \\
\text { Mod. Const. } \\
\text { Mod. Const. } \\
\text { Release } \\
\text { Release } \\
\text { Severe Const. } \\
\text { Severe Const. } \\
\text { Release } \\
\text { Release }\end{array}$ & $\begin{array}{r}\min . \\
0 \\
10 \\
230 \\
241 \\
291 \\
301 \\
336 \\
346 \\
410 \\
420 \\
445 \\
455\end{array}$ & $\begin{array}{c}m m . H g \\
185 \\
184 \\
155 \\
155 \\
127 \\
130 \\
130 \\
130 \\
95 \\
100 \\
110 \\
110\end{array}$ & $\begin{array}{c}m m . H_{2} O \\
- \\
50 \\
55 \\
115 \\
125 \\
80 \\
80 \\
125 \\
95 \\
65 \\
80\end{array}$ & $\begin{array}{c}\text { l./min. } \\
3.64 \\
3.86 \\
1.63 \\
1.58 \\
1.01 \\
1.14 \\
2.52 \\
2.69 \\
1.52 \\
1.59 \\
2.38 \\
2.47\end{array}$ & $\begin{array}{c}c c . / \min . \\
500 \\
522 \\
314 \\
334 \\
323 \\
269 \\
297 \\
265 \\
199 \\
161 \\
205 \\
217\end{array}$ & $\begin{array}{c}\text { per crnt } \\
13.7 \\
13.5 \\
19.3 \\
21.2 \\
32.0 \\
23.6 \\
11.8 \\
10.2 \\
13.1 \\
10.1 \\
8.6 \\
8.8\end{array}$ & $\begin{array}{c}c c . / \min . \\
83.0 \\
86.0 \\
66.6 \\
72.3 \\
63.2 \\
52.8 \\
53.8 \\
50.7 \\
38.8 \\
33.7 \\
37.3 \\
41.4\end{array}$ & $\begin{array}{l}.330 \\
.338 \\
.374 \\
.389 \\
.368 \\
.388 \\
.289 \\
.313 \\
.362 \\
.383 \\
.289 \\
.316\end{array}$ & $\begin{array}{r}4.06 \\
3.81 \\
7.60 \\
7.84 \\
10.04 \\
9.11 \\
4.12 \\
3.86 \\
4.99 \\
5.03 \\
3.69 \\
3.56\end{array}$ & $\begin{array}{l}29.6 \\
28.2 \\
39.4 \\
37.1 \\
31.4 \\
38.6 \\
35.0 \\
39.2 \\
38.1 \\
49.6 \\
42.9 \\
40.5\end{array}$ \\
\hline $\begin{array}{l}\text { BL } 25 \\
(19.5 \mathrm{~kg} .) \\
(145 \mathrm{gm} .)\end{array}$ & $\begin{array}{l}\text { Pre-op. } \\
\text { Control } \\
\text { Post-op. } \\
\text { Control } \\
\text { Mod. Const. } \\
\text { Mod. Const. } \\
\text { Mod. Const. } \\
\text { Mod. Const. }\end{array}$ & $\begin{array}{r}0 \\
10 \\
125 \\
135 \\
226 \\
236 \\
298 \\
308\end{array}$ & $\begin{array}{l}150 \\
155 \\
123 \\
120 \\
100 \\
105 \\
102 \\
108\end{array}$ & $\begin{array}{l}- \\
\overline{70} \\
70 \\
100 \\
100 \\
110 \\
110\end{array}$ & $\begin{array}{l}3.41 \\
3.06 \\
1.34 \\
1.31 \\
1.04 \\
1.07 \\
0.98 \\
0.94\end{array}$ & $\begin{array}{l}442 \\
462 \\
278 \\
264 \\
201 \\
227 \\
164 \\
178\end{array}$ & $\begin{array}{l}13.0 \\
15.1 \\
20.8 \\
20.2 \\
19.3 \\
21.2 \\
16.7 \\
18.9\end{array}$ & $\begin{array}{l}96.5 \\
92.8 \\
70.1 \\
74.2 \\
70.6 \\
72.0 \\
51.0 \\
54.4\end{array}$ & $\begin{array}{l}.344 \\
.322 \\
.398 \\
.452 \\
.538 \\
.493 \\
.477 \\
.469\end{array}$ & $\begin{array}{l}3.52 \\
4.05 \\
7.33 \\
7.32 \\
7.68 \\
7.84 \\
8.32 \\
9.18\end{array}$ & $\begin{array}{l}27.1 \\
26.8 \\
35.4 \\
36.3 \\
39.6 \\
37.0 \\
49.7 \\
48.5\end{array}$ \\
\hline $\begin{array}{l}\text { BL } 26 \\
(19.0 \mathrm{~kg} .) \\
(128 \mathrm{gm} .)\end{array}$ & $\begin{array}{l}\text { Pre-op. } \\
\text { Control } \\
\text { Post-op. } \\
\text { Control } \\
\text { Slight } \\
\text { Constr. } \\
\text { Release } \\
\text { Release } \\
\text { Mod. Const. } \\
\text { Mod. Const. } \\
\text { Release } \\
\text { Release }\end{array}$ & $\begin{array}{r}0 \\
10 \\
172 \\
187 \\
231 \\
241 \\
294 \\
304 \\
354 \\
364 \\
395 \\
405\end{array}$ & $\begin{array}{r}153 \\
154 \\
138 \\
135 \\
123 \\
110 \\
112 \\
104 \\
86 \\
80 \\
91 \\
86\end{array}$ & $\begin{array}{l}- \\
38 \\
38 \\
85 \\
85 \\
47 \\
48 \\
80 \\
80 \\
60 \\
60\end{array}$ & $\begin{array}{l}2.43 \\
2.81 \\
1.62 \\
1.55 \\
1.71 \\
1.81 \\
2.08 \\
2.04 \\
1.35 \\
1.33 \\
2.11 \\
2.16\end{array}$ & $\begin{array}{l}442 \\
488 \\
359 \\
423 \\
340 \\
305 \\
375 \\
424 \\
332 \\
391 \\
397 \\
500\end{array}$ & $\begin{array}{l}18.2 \\
17.4 \\
22.2 \\
27.3 \\
19.9 \\
16.9 \\
18.0 \\
20.8 \\
24.6 \\
29.4 \\
18.8 \\
23.1\end{array}$ & $\begin{array}{l}99.2 \\
95.7 \\
72.2 \\
78.0 \\
81.6 \\
74.0 \\
83.2 \\
86.4 \\
72.0 \\
68.2 \\
68.0 \\
75.4\end{array}$ & $\begin{array}{l}.367 \\
.351 \\
.342 \\
.322 \\
.392 \\
.402 \\
.371 \\
.345 \\
.364 \\
.298 \\
.268 \\
.255\end{array}$ & $\begin{array}{l}5.03 \\
4.38 \\
6.82 \\
6.95 \\
5.75 \\
4.87 \\
4.30 \\
4.08 \\
5.09 \\
4.82 \\
3.44 \\
3.18\end{array}$ & $\begin{array}{l}27.6 \\
25.2 \\
30.8 \\
25.6 \\
28.9 \\
28.9 \\
23.9 \\
19.6 \\
20.7 \\
16.4 \\
18.3 \\
13.8\end{array}$ \\
\hline
\end{tabular}

after the onset of anesthesia are probably close to expected pre-anesthesia levels, since they agree well with values reported by numerous other investigators using the Fick principle in unanesthetized dogs (Table III).

In the three experiments in which pre-operative cardiac output determinations were made (BL 24,25 , and 26), the output of the heart was diminished by 57,59 , and 39 per cent, respectively, as the

TABLE II

Extraction ratios for $P A H$ during acute pulmonary artery constriction

\begin{tabular}{l|c|c|c}
\hline \multicolumn{1}{c|}{ Period } & $\begin{array}{c}\text { Mean } \\
\text { arterial } \\
\text { pressure }\end{array}$ & $\begin{array}{c}\text { Right } \\
\text { atrial } \\
\text { pressure }\end{array}$ & $\begin{array}{c}\text { Extraction } \\
\text { ratio of } \\
\text { left kidney }\end{array}$ \\
\cline { 2 - 2 } $\mathrm{Hg}$ & $\mathrm{mm.} \mathrm{H}_{2} \mathrm{O}$ & per cent \\
Pre-op. control & 167 & - & 78.7 \\
Post-op. control & 144 & 64 & 76.6 \\
Mod. constriction & 143 & 104 & 81.8 \\
Release & 143 & 84 & 82.8 \\
Severe constriction & 90 & 136 & 80.9 \\
Release & 133 & 76 & 79.5 \\
\hline
\end{tabular}

result of operative procedures and/or opening of the chest. However, it is exceedingly unlikely that a reduction of such great magnitude occurred in experiments $\mathrm{BL} 10,11$, and 16 , since the postoperative cardiac outputs in these experiments were all greater than $31 . / \mathrm{min}$.

Table I also shows that compression of the pulmonary artery causes a further decline in cardiac output beyond the post-operative control value,

TABLE III

Comparison of our cardiac output data in pentobarbitalized dogs with those of other investigators in unanesthetized dogs

\begin{tabular}{lcc}
\multicolumn{1}{c}{ Investigator } & Anesthesia Mean cardiac index* \\
Marshall (14) & Unanesthetized & 3.09 \\
Harrison and associates (15) & Unanesthetized & 4.12 \\
Stewart and Gilchrist (16) & Unanesthetized & 2.58 \\
Cohn and Stewart (17) & Unanesthetized & 6.41 \\
Rasmussen (18) & Unanesthetized & 2.75 \\
Our studies & Pentobarbital & 3.90 \\
* Cardiac index is defined as cardiac output per minute \\
per sq. meter of body surface (Meeh's formula). The \\
cardiac output in all cases was determined by means of the \\
Fick principle.
\end{tabular}

Anesthesia Mean cardiac index* Unanesthetized Unanesthetized $\quad 2.58$ Unanesthetized $\quad 6.41$ $\begin{array}{ll}\text { Unanesthetized } & 2.75 \\ \text { Pentobarbital } & 3.90\end{array}$

Our studies

cardiac output in all cases was determined by means of the Fick principle. 
with a return toward control following release of constriction. Comparative analysis of the concurrent changes in mean arterial pressure reveals that the arterial pressure falls to a much lesser extent than does the cardiac output, indicating that some mechanism acts to support the arterial pressure in the face of a reduction of cardiac output. This phenomenon will be discussed in more detail in connection with total peripheral resistance.

Of the three variables involved in the determination of cardiac output by the Fick principle, the oxygen consumption and the arterial oxygen content remained relatively constant during the various experimental procedures. The oxygen content of the mixed venous blood, however, varied considerably with changes in cardiac output, and is the principal variable also in most cases of clinical congestive heart failure $(19,20)$.

Renal blood flow. The possible effects of anesthesia should be considered in interpreting the changes in effective renal blood flow which were observed in our experiments. It has been amply demonstrated that renal blood flow determinations made soon after the onset of pentobarbital anesthesia do not appreciably differ from pre-anesthesia controls (21-23). In our experiments, most of the post-anesthesia control renal blood flows were from 400 to $500 \mathrm{cc}$. $/ \mathrm{min}$. Therefore, it is evident that anesthesia did not significantly impair the renal circulation early in each experiment. Studies by Selkurt, Hall, and Spencer (6), however, have revealed a tendency for a gradual fall in renal blood flow to occur in pentobarbitalized dogs over the course of several hours, even when subjected to no experimental procedures. This probably is partially responsible for the failure of the effective renal blood flow to return completely to control levels after release of pulmonary artery constriction.

Further comparison of our data with those obtained from studies on unanesthetized dogs also fails to reveal any appreciable effect of pentobarbital upon the effective renal fraction (the ratio of the effective renal blood flow to the cardiac output). In our pre-operative studies, effective renal fractions ranged from 13.0 to 18.2 per cent, with an average of 15.2 per cent. Levy and Blalock (24), using direct flow measurements, obtained an average of 18.5 per cent in unanesthetized dogs, with a variation from 10.4 to 25.7 per cent, while renal fractions calculated from data presented by Bing, Thomas, and Waples (25) ranged from 8.3 to 22.4 per cent in unanesthetized dogs. Our data, therefore, fall well within the ranges reported in unanesthetized dogs.

From Table $I$ it is evident that reduction of the output of the heart by compression of the pulmonary artery diminishes the quantity of blood flowing through the kidneys. The renal blood flow is reduced proportionately less, however, than is the cardiac output, as illustrated in Figure 1, where the effective renal blood flow during constriction periods is plotted against cardiac output, both in terms of per cent of post-operative control. In this figure, all points would fall about the diagonal line if the renal blood flow fell commensurately with the reduction in cardiac output. The majority of points, however, fall above this line; in fact, when the cardiac output is depressed to below 70 per cent of control, all points fall above this line.

This phenomenon is presented in another fashion in Figure 2 in which the effective renal fraction is plotted in terms of per cent of post-operative control for the entire series of experiments, according to experimental periods. The horizontal line

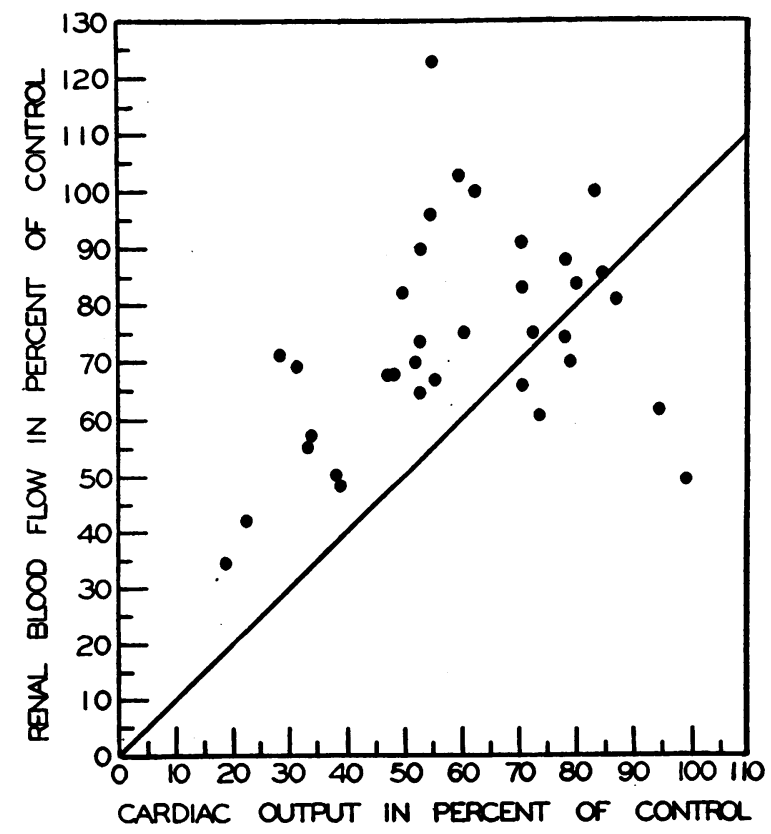

Fig. 1. Plot of Renal Blood Flow against Cardiac Output during Acute Pulmonary Artery ConstricTION 


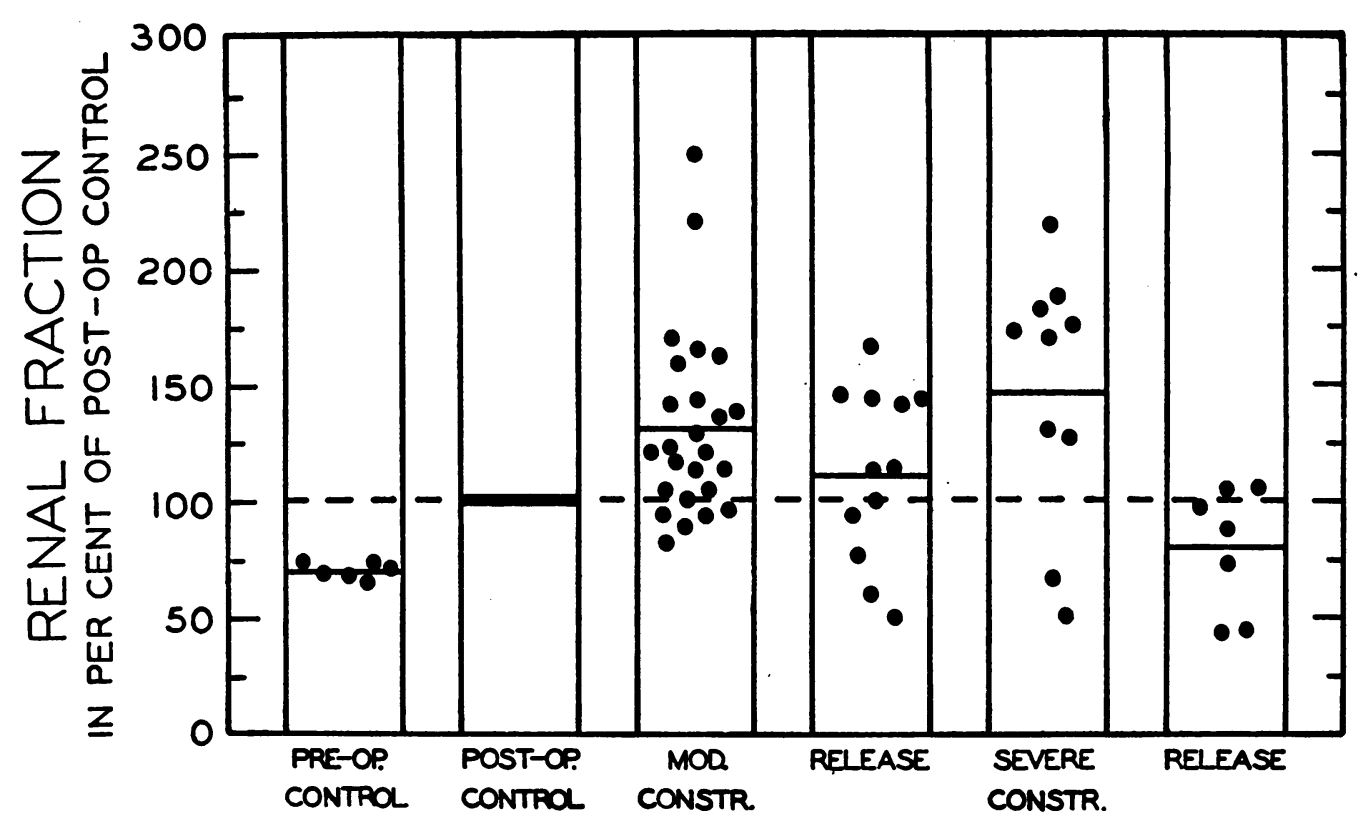

Fig. 2. Changes in the Effective Renal Fraction during Control, Constriction, and Recovery PERIODS

Solid horizontal lines in each period represent the mean effective renal fraction.

in each period represents the mean effective renal fraction for that period. It is evident that moderate and severe constriction of the pulmonary artery significantly elevates the renal fractions, and with release of constriction the renal fractions return approximately to control values. Therefore, simple reduction of cardiac output without marked lowering of arterial pressure produces a disproportionately smaller decrease in renal blood flow, with the result that a larger fraction of the cardiac output circulates through the kidneys. It is of interest to note that even when cardiac output is diminished after surgical procedures the renal blood flow is reduced to a lesser extent, as reflected in the higher post-operative renal fractions as compared to the pre-operative values. This parallels the findings reported by Phillips and his associates (23) in dogs after moderate hemorrhage. They observed that the renal circulation tends to be spared at the expense of the peripheral circulation before true, irreversible shock supervenes.

Extraction ratios for $\mathrm{PAH}$ were not expected to change during the course of our experiments, since Phillips and his colleagues (23) had to reduce the renal blood flow to 3 per cent of normal before $\mathrm{PAH}$ extraction was impaired. Nevertheless, we did perform one experiment in which extraction ratios were determined during experimental periods similar to those in our previous experiments, and the results are presented in Table II. It is apparent that no significant alteration in the capacity of the renal tubules to extract PAH was incurred as the result of compression of the pulmonary artery. However, even if impairment of renal tubular function had occurred during any of our experiments due to the diminished renal blood flow, the actual renal blood flow and renal fraction would have been even greater than that shown in Table I.

Glomerular filtration rate and filtration fraction. In some experiments, the glomerular filtration rate remained almost constant with the decrease in cardiac output and renal plasma flow, while in others it fell, but at a much slower rate than did plasma flow (Table I). Consequently, there was a rise in the filtration fraction in all cases. A good part of this rise in the filtration fraction is probably attributable to the operative procedures and prolonged state of anesthesia, but constriction of the pulmonary artery produced further elevation of the filtration fraction which was not always maintained upon release of the constriction. The recent work of Selkurt, Hall, and Spencer (6) excludes the possibility that the elevated filtration fraction 
is due to the increased renal venous pressure. Therefore, the increased renal fraction is probably dependent upon changes in afferent and efferent arteriolar resistance. These changes will be analyzed in more detail in the section on resistances.

Changes in total peripheral and renal resistances. Total peripheral resistance (T.P.R.) and renal resistance $\left(R_{k}\right)$ were calculated for each period, and the results expressed in absolute units (dynes $\mathrm{cm}^{-5} \mathrm{sec}$.), by means of the following formulae:

$$
\begin{aligned}
\text { T.P.R. } & =\frac{\text { M.A.P. } \times 1332}{\text { C.O. }(\text { cc. } / \text { sec.) }} \\
R_{k} & =\frac{\text { M.A.P. } \times 1332}{\text { R.B.F. }(\text { cc. } / \text { sec.) }}
\end{aligned}
$$

M.A.P. $\times 1332$ represents the mean arterial pressure in terms of dynes per sq. cm., and renal blood flow (R.B.F.), and cardiac output (C.O.) are expressed in terms of $\mathrm{cc}$./sec. Mean right atrial and mean renal venous pressures were not subtracted from the mean arterial pressures in these calculations, since the venous pressures are virtually negligible as compared to arterial pressures.

Figure 3 illustrates the changes which occur in T.P.R. and $R_{k}$ during the various experimental periods. Both sets of resistances are expressed as per cent of post-operative controls. Comparison with control studies reveals that moderate and severe constriction of the pulmonary artery produced increases in T.P.R. and $R_{k}$, but the changes in T.P.R., both as a result of the operative procedure and of pulmonary artery stenosis, were relatively much greater than were the changes in $R_{k}$. Also, the T.P.R. tended to return more toward control during release periods, while $R_{k}$ tended to show a gradual increase over the course of the experiment, with no statistically significant changes between periods of constriction and release.

It is, of course, not valid to predict changes in vasomotor tone on the basis of resistance changes alone. As Green and his colleagues (26) emphasize, the pressure-flow relationship for various tissues is not linear, even when vasomotor tone is constant. Therefore, resistance may vary with changes in pressure or flow even when vasomotor tone remains unaltered. However, if changes in flow are observed at constant pressures, or changes in pressure at constant flows, then one can validly draw conclusions concerning vasomotor activity from resistance calculations, provided other factors (especially hematocrit) remain constant.

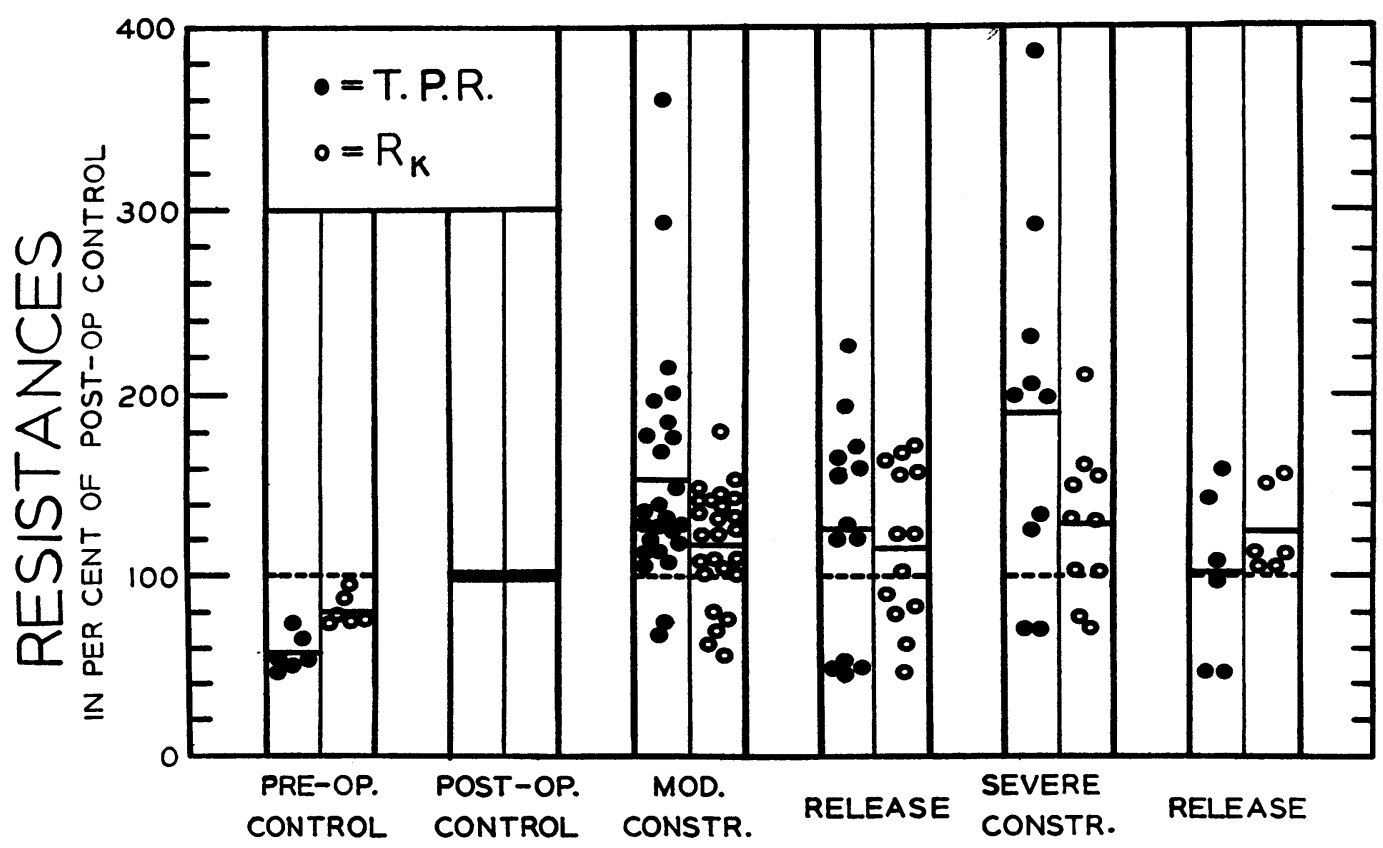

Fig. 3. Changes in Total Peripheral Resistance (T.P.R.) and Renal Resistance (Rx) During Control, Constriction, and Recovery Periods

Solid horizontal lines in each period represent the mean resistance. 
TABLE IV

Renal afferent and efferent arteriolar resistance*

\begin{tabular}{|c|c|c|c|c|c|c|c|c|c|c|c|c|c|c|c|c|}
\hline \multirow{2}{*}{$\begin{array}{l}\text { Expt. No.................... } \\
\text { Procedures..... }\end{array}$} & \multicolumn{2}{|c|}{ BL 10} & \multicolumn{2}{|c|}{ BL 11} & \multicolumn{2}{|c|}{ BL 15} & \multicolumn{2}{|c|}{ BL 16} & \multicolumn{2}{|c|}{ BL 19} & \multicolumn{2}{|c|}{ BL 24} & \multicolumn{2}{|c|}{ BL 25} & \multicolumn{2}{|c|}{ BL 26} \\
\hline & $\mathbf{R}_{\mathbf{A}}$ & $\mathbf{R}_{\mathbf{E}}$ & $\mathbf{R}_{\mathbf{A}}$ & $\mathbf{R}_{\mathbf{E}}$ & $\mathbf{R}_{\mathbf{A}}$ & $\mathbf{R}_{\mathbf{E}}$ & $\mathbf{R}_{\mathbf{A}}$ & $\mathbf{R}_{\mathbf{E}}$ & $\mathbf{R}_{\mathbf{A}}$ & $\mathbf{R}_{\mathbf{E}}$ & $\mathbf{R}_{\mathbf{A}}$ & $\mathbf{R E}_{\mathbf{E}}$ & $\mathbf{R}_{\mathbf{A}}$ & $\mathbf{R}_{\mathbf{E}}$ & $\mathbf{R}_{\mathbf{A}}$ & $\mathbf{R}_{\mathbf{E}}$ \\
\hline Pre-op. control & - & - & - & - & 一 & - & 一 & 一 & 一 & - & .219 & .030 & .186 & .040 & .174 & .044 \\
\hline Post-op. control & .119 & .038 & .091 & .038 & .211 & .145 & .214 & .010 & .049 & .037 & .241 & .067 & .141 & .170 & .151 & .038 \\
\hline Mod. constr. & .007 & .118 & -.0198 & .185 & .016 & .169 & .100 & .123 & $-.003+8$ & .107 & .173 & .070 & $.000 \ddagger$ & $.233 t$ & .118 & .076 \\
\hline Severe constr. & -.0468 & .128 & 一 & - & - & 一 & 一 & 一 & 一 & - & - & 一 & 一 & 一 & 一 & - \\
\hline Release & -.0148 & .194 & -.0378 & .199 & .105 & .164 & .123 & .089 & .017 & .140 & .220 & .054 & - & 一 & .090 & .051 \\
\hline Severe constr. & -.3168 & .364 & - & - & -.2538 & .391 & .045 & .170 & - & - & .122 . & .113 & 一 & - & .037 & .047 \\
\hline Release & 一 & 一 & 一 & - & -.0198 & .385 & .118 & .159 & 一 & - & .209 & .072 & - & - & .041 & .025 \\
\hline
\end{tabular}

* $\mathbf{R}_{\mathbf{A}}=$ renal afferent arteriolar resistance expressed in $\mathrm{mm} . \mathrm{Hg} / \mathrm{cc} . / \mathrm{min}$.

$\mathrm{R}_{\mathrm{E}}=$ renal efferent arteriolar resistance expressed in $\mathrm{mm} . \mathrm{Hg} / \mathrm{cc} . / \mathrm{min}$.

$\dagger$ Average of 10 determinations.

$\ddagger$ Average of four determinations. All other figures are averages of two determinations.

$\$$ Negative values indicate a breakdown of the formula for afferent resistance when mean blood pressure is low and filtration fraction very high (as noted by Lamport [42]). These figures nevertheless are useful in demonstrating the directional changes in afferent resistance.

In our fifth experiment (Table I), where moderate constriction was maintained for four hours, there was no significant alteration in mean arterial pressure, but the cardiac output was reduced to between one-third and one-half of control levels. In this experiment, therefore, it is valid to conclude that generalized vasoconstriction had taken place. In most of the other experiments, the mean arterial pressure fell only slightly compared to the decrease in cardiac output, and it is reasonable to conclude that vasoconstriction was present in most of these cases.

Although the increase in total renal resistance was relatively, insignificant following acute reduction of cardiac output, application of Lamport's formulae (27) to our data reveals marked changes in the component afferent and efferent arteriolar resistances. Table IV shows that afferent arteriolar resistance fell with constriction of the pulmonary artery, accompanied by a rise in efferent resistance. With release, there was a return toward control values. Unpublished data from our laboratory have demonstrated parallel pressure changes in the right atrium and renal veins following experimental pulmonary artery stenosis in open-chested dogs. On this basis, post-arteriolar resistances were calculated, substituting right atrial for renal venous pressures, and it was found that only small increases in post-arteriolar resistance occurred with reduction of the cardiac output. Plasma protein concentrations were not determined in our experiments, but a value of $6 \mathrm{gm} . / 100 \mathrm{cc}$. was assumed in our calculations. This would, of course, introduce a slight error, but it would not affect the relatively large directional changes in afferent and efferent arteriolar resistances.

\section{DISCUSSION}

In a large series of patients with congestive heart failure, studies by Merrill (1) have revealed a reduction in the cardiac output with a proportionately greater decrease in the renal blood flow, resulting in a markedly diminished renal fraction. In our acute experiments, however, the contrary proved to be true; namely, a relatively smaller reduction in renal blood flow than in cardiac output, with an elevation of the renal fraction. Several factors should be considered in an attempt to explain this disparity. It has already been indicated that anesthesia is probably not responsible for this difference, since cardiac outputs, renal blood flows, and renal fractions in our control animals are similar to those in unanesthetized dogs. Also, shock secondary to operative procedures or occurring in the course of the experiment does not play a role, since blood pressures never fell below 
$80 \mathrm{~mm} . \mathrm{Hg}$ even during constriction periods. Nor can the disparity be attributed to structural or physiological differences in the circulation of the kidneys in man and the dog. Trueta and his coworkers (28) have demonstrated the structural similarity, and Reubi and Schroeder (29) present fairly conclusive evidence that physiologically renal vascular shunts do not operate in either man or the dog. It is possible that in clinical congestive heart failure the reduced cardiac output acts indirectly to produce a decreased renal fraction by means of a delayed nervous mechanism, or more likely by some humoral factor (such as renin or V.E.M.). If such factors do come into play, they may not be elicitable in an experiment of short duration (maximum of four hours of maintained constriction) and would require chronic studies for more satisfactory evaluation.

On the other hand, studies on patients with congestive heart failure may not define cause and effect relationships with certainty. It is virtually impossible to compare the data for cardiac output and renal blood flow in a patient with congestive heart failure with the control values of that particular subject prior to the onset of the cardiac disease. The extremely wide range of renal fractions in normal human subjects (from 10 to 27 per cent) (30) emphasizes the importance of knowing the control value for each individual case. Furthermore, emotional disturbances and increased muscular activity (dyspnea, muscular tension, etc.) may be pronounced in patients suffering from congestive heart failure, even when ostensibly at rest. These factors are known to increase the cardiac output and decrease the renal blood flow (31-35), thereby militating toward a reduced renal fraction. It must finally be mentioned that a marked impairment of renal blood flow is not an invariable accompaniment of heart failure, since decompensated patients have been described with renal flows within the range of normal, or only slightly reduced $(36,37)$. If, however, a reduced renal fraction is characteristic of the majority of cases of chronic congestive heart failure, cautious application of our observations to clinical heart failure suggests that the diminution in cardiac output per se is not directly responsible for this relatively greater decrease in renal blood flow. Studies by Mokotoff and Ross (38) indicate that the renal vasoconstriction reported in clinical cases is prob- ably not dependent upon a neurogenic mechanism. They submitted decompensated subjects to high spinal anesthesia, and observed no significant change in the renal blood flow. By exclusion, therefore, they postulated a humoral factor initiating the renal vasoconstriction, and conjectured that once this relative renal ischemia occurred, generalized vasoconstriction would be produced through the elaboration of renin or V.E.M. Subsequently, Mokotoff and his coworkers (39) reported the presence of V.E.M. in the renal venous blood in every case of cardiac failure studied. In addition, in eight of 11 decompensated patients studied by Merrill, Morrison, and Brannon (40) the renin content of the renal venous blood was found to be increased. Thus, it is possible that such humoral mechanisms may be operative in clinical heart failure to produce the observed increase in total peripheral resistance. In our acute experiments, however, marked alterations in total peripheral resistance could be elicited in a matter of a few seconds, indicating a neurogenic mechanism. The degree of change in total peripheral resistance in our experiments was of a similar order of magnitude to that occurring in clinical heart failure, while the changes in total renal resistance were relatively slight.

Just what factors operate to apportion the circulating blood to the various organs and tissues under conditions of reduced cardiac output by regulating their individual resistances is still not clear, but evidence has recently been presented which demonstrates the ability of the kidney to maintain its flow in the face of diminishing arterial pressure. Selkurt, Hall, and Spencer (5) observed that a decrease in renal arterial pressure resulted in a drop in afferent arteriolar resistance with no significant change in efferent resistance. The afferent arteriolar changes appear to be due to an intrinsic mechanism within the kidney, for even in the denervated kidney, flows tend to remain fairly constant over a wide range of arterial pressures $(5,41)$.

The marked reduction in renal blood flow in clinical congestive heart failure has been ascribed principally to an efferent arteriolar vasoconstriction $(1,2)$. We applied Lamport's formulae $(27)$ to Merrill's data on patients with rheumatic heart disease, assuming normal blood pressures, and found the values for efferent resistance to be increased up to 20 -fold, while the average afferent re- 
sistance was slightly elevated but still within the limits of normal (42).

In our experiments, we observed a decrease in afferent resistance and an increase in efferent resistance, both of significant magnitude, but with only a slight increase in the total renal resistance as the cardiac output was reduced. The decline in afferent resistance is probably on the same basis as the intrinsic, autonomous adjustment noted with experimental variations in arterial pressure. However, the efferent vasoconstriction appears to be extra-renal in origin, since such changes were observed only when cardiac output was acutely reduced, but not when the arterial pressure to the kidney alone was diminished.

\section{SUMMARY}

Acute reduction of cardiac output was produced in dogs by means of graded constriction of the pulmonary artery. Changes in arterial and central venous pressures were measured by means of optical manometers in some experiments and by mercury and water manometers in others. Alterations in cardiac output were determined by the Fick procedure, and renal circulatory data obtained by clearance techniques. Experimental observations were made during pre-operative and post-operative control periods, during periods of acutely reduced cardiac output, and during subsequent recovery periods.

Effective renal blood flow was diminished by compression of the pulmonary artery, but to a lesser degree than the cardiac output, resulting in a significant elevation of the renal fraction. Mean arterial pressure fell slightly, and in no case below $80 \mathrm{~mm}$. $\mathrm{Hg}$. Glomerular filtration rate remained unchanged or decreased somewhat, producing a rise in the filtration fraction.

Acute reduction of the cardiac output elicited a relatively large increase in the total peripheral resistance, but only a comparatively slight augmentation of the total renal resistance. Analysis of the changes in renal resistance by Lamport's formulae indicates a significant increase in efferent arteriolar resistance countered by a decrease in afferent resistance.

\section{ACKNOWLEDGMENTS}

We are deeply indebted to Drs. Carl J. Wiggers and Ewald E. Selkurt for their guidance during this research and for their suggestions in the preparation of the manuscript.

\section{BIBLIOGRAPHY}

1. Merrill, A. J., Edema and decreased renal blood flow in patients with chronic congestive heart failure. Evidence of "forward failure" as the primary cause of edema. J. Clin. Invest., 1946, 25, 389.

2. Mokotoff, R., Ross, G., and Leiter, L., Renal plasma flow and sodium reabsorption and excretion in congestive heart failure. J. Clin. Invest., 1948, 27, 1.

3. Levy, M. N., and Berne, R. M., Production of acute experimental circulatory failure by graded pulmonary artery constriction. Proc. Soc. Exper. Biol. \& Med., 1949, 72, 147.

4. Selkurt, E. E., The relation of renal blood flow to effective arterial pressure in the intact kidney of the dog. Am. J. Physiol., 1946, 147, 537.

5. Selkurt, E. E., Hall, P. W., and Spencer, M. P., Influence of graded arterial pressure decrement on renal clearance of creatinine, p-aminohippurate, and sodium. Am. J. Physiol., 1949, 159, 369.

6. Selkurt, E. E., Hall, P. W., and Spencer, M. P., Response of renal blood flow and clearance to graded partial obstruction of the renal vein. Am. J. Physiol., 1949, 157, 40.

7. Blake, W. D., Wégria, R., Keating, R. P., and Ward, $H$. P., Effect of increased renal venous pressure on renal function. Am. J. Physiol., 1949, 157, 1.

8. Opdyke, D. F., Duomarco, J., Dillon, W. H., Schreiber, H., Little, R. C., and Seely, R. D., Study of simultaneous right and left atrial pressure pulses under normal and experimentally altered conditions. Am. J. Physiol., 1948, 154, 258.

9. Harris, A. S., and Matlock, W. P., The effects of anoxemic anoxia on excitability, conduction, and refractoriness of mammalian cardiac muscle. Am. J. Physiol., 1947, 150, 493.

10. Roughton, F. J. W., and Scholander, P. F., Microgasometric estimation of the blood gases. I. Oxygen. J. Biol. Chem., 1943, 148, 541.

11. Folin, $\mathrm{O}$., and $\mathrm{Wu}, \mathrm{H}$., A system of blood analysis. J. Biol. Chem., 1919, 38, 81.

12. Smith, H. W., Finkelstein, N., Aliminosa, L., Crawford, B., and Graber, M., The renal clearances of substituted hippuric acid derivatives and other aromatic acids in dogs and man. J. Clin. Invest., 1945, 24, 388.

13. Shore, R., Holt, J. P., and Knoefel, P. K., Determination of cardiac output in the dog by the Fick procedure. Am. J. Physiol., 1945, 143, 709.

14. Marshall, E. K., Jr., Studies on the cardiac output of the dog. I. The cardiac output of the normal unanesthetized dog. Am. J. Physiol., 1926, 77, 459.

15. Harrison, T. R., Wilson, C. P., Neighbors, DeW., and Pilcher, C., The regulation of circulation. VII. The effects of anoxemia of mild degree on the cardiac output of unnarcotized dogs. Am. J. Physiol., 1927, 83, 275. 
16. Stewart, H. J., and Gilchrist, A. R., Studies on the effect of cardiac irregularity on the circulation. II. The estimation of cardiac output in dogs subject to artificial auricular fibrillation. J. Clin. Invest., 1927, 5, 335.

17. Cohn, A. E., and Stewart, H. J., The relation between cardiac size and cardiac output per minute following the administration of digitalis in normal dogs. $\mathrm{J}$. Clin. Invest., 1928, 6, 53.

18. Rasmussen, $H$., Influence of the thyroid hormone on heart and circulation. Acta med. Scandinav., 1941, Suppl. 115.

19. Stead, E. A., Jr., Warren, J. V., and Brannon, E. S., Cardiac output in congestive heart failure. Am. Heart J., 1948, 35, 529.

20. Briggs, A. P., Fowell, D. M., Hamilton, W. F., Remington, J. W., Wheeler, N. C., and Winslow, J. A., Renal and circulatory factors in the edema formation of congestive heart failure. J. Clin. Invest., 1948, 27, 810.

21. Corcoran, A. C., and Page, I. H., Effects of anesthetic dosage of pentobarbital sodium on renal function and blood pressure in dogs. Am. J. Physiol., 1943, 140, 234.

22. Selkurt, E. E., The changes in renal clearance following complete ischemia of the kidney. Am. J. Physiol., 1945, 144, 395.

23. Phillips, R. A., Dole, V. P., Hamilton, P. B., Emerson, K., Jr., Archibald, R. M., and Van Slyke, D. D., Effects of acute hemorrhagic and traumatic shock on renal function of dogs. Am. J. Physiol., 1946, 145, 314.

24. Levy, S. E., and Blalock, A., Fractionation of the output of the heart and of oxygen consumption of normal unanesthetized dogs. Am. J. Physiol., 1937, 118, 368.

25. Bing, R. J., Thomas, C. B., and Waples, E. C., The circulation in experimental neurogenic hypertension. J. Clin. Invest., 1945, 24, 513.

26. Green, H. D., Lewis, R. N., Nickerson, N. D., and Heller, A. L., Blood flow, peripheral resistance and vascular tonus, with observations on the relationship between blood flow and cutaneous temperature. Am. J. Physiol., 1944, 141, 518.

27. Lamport, H., Improvements in calculation of renal resistance to blood flow. Charts for osmotic pressure and viscosity of blood. J. Clin. Invest., 1943, 22, 461.

28. Trueta, J., Barclay, A. E., Daniel, P. M., Franklin, K. J., and Prichard, M. M. L., Studies of the Renal Circulation. Charles C. Thomas Co., Springfield, III., 1947.

29. Reubi, F. C., and Schroeder, H. A., Can vascular shunting be induced in the kidney by vasoactive drugs? J. Clin. Invest., 1949, 28, 114.

30. Bolomey, A. A., Michie, A. J., Michie, C., Breed, E. S., Schreiner, G. E., and Lauson, H. D., Simultaneous measurement of effective renal blood flow and cardiac output in resting normal subjects and patients with essential hypertension. J. Clin. Invest., 1949, 28, 10.

31. Stead, E. A., Jr., Warren, J. V., Merrill, A. J., and Brannon, E. S., The cardiac output in male subjects as measured by the technique of right atrial catheterization. Normal values with observations on the effect of anxiety and tilting. J. Clin. Invest., 1945, 24, 326 .

32. Hickam, J. B., and Cargill, W. H., Effect of exercise on cardiac output and pulmonary arterial pressure in normal persons and in patients with cardiovascular disease and pulmonary emphysema. J. Clin. Invest., 1948, 27, 10.

33. Hickam, J. B., Cargill, W. H., and Golden, A., Cardiovascular reactions to emotional stimuli. Effect on the cardiac output, arteriovenous oxygen difference, arterial pressure, and peripheral resistance. J. Clin. Invest., 1948, 27, 290.

34. Merrill, A. J., and Cargill, W. H., The effect of exercise on the renal plasma flow and filtration rate of normal and cardiac subjects. J. Clin. Invest., 1948, 27, 272.

35. Chapman, C. B., Henschel, A., Minckler, J., Forsgren, A., and Keys, A., The effect of exercise on renal plasma flow in normal male subjects. J. Clin. Invest., 1948, 27, 639.

36. Farnsworth, E. B., and Krakusin, J. S., Electrolyte partition in patients with edema of various origins: qualitative and quantitative definition of cations and anions in cardiac decompensation. J. Lab. \& Clin. Med., 1948, 33, 1534.

37. Highes, D. J., Turner, H. H., Moseley, A. J., and Merrill, A. J., Mechanisms of salt and water retention in heart failure. Am. J. Med., 1949, 7, 249.

38. Mokotoff, R., and Ross, G., The effect of spinal anesthesia on the renal ischemia in congestive heart failure. J. Clin. Invest., 1948, 27, 335.

39. Mokotoff, R., Escher, D. J. W., Edelman, I. S., Grossman, J., Leiter, L., Weston, R. E., Zweifach, B. W., and Shorr, E., Studies on vasotropic principles in blood (VEM and VDM) and renal hemodynamics in chronic heart failure. Federation Proc., 1949, 8, 112.

40. Merrill, A. J., Morrison, J. L., and Brannon, E. S., Concentration of renin in renal venous blood in patients with chronic heart failure. Am. J. Med., 1946, 1, 468.

41. Forster, R. P., and Maes, J. P., Effect of experimental neurogenic hypertension on renal blood flow and glomerular filtration rates in intact denervated kidneys of unanesthetized rabbits with adrenal glands demedullated. Am. J. Physiol., 1947, 150, 534.

42. Lamport, H., Formulae for afferent and efferent arteriolar resistance in the human kidney. An application to the effects of spinal anesthesia. J. Clin. Invest., 1941, 20, 535. 